\title{
Herman ve Chomsky'nin Propaganda Modeli Süzgeci Olan Kitle Medyasının Büyüklüğü ve Kar Anlayışı Üzerinden Tekelleşme ve Türk Medyasının Tekelleşmesinin İncelenmesi
}

\author{
Murat ÇAKMAK*
}

* Doktora Öğrencisi, Süleyman Demirel Üniversitesi, murat.cakmakk@yahoo.com Orcid ID: 0000-0002-1727-9314

Gönderilme/ Received 27.09.2021

Kabul Tarihi/ Accepted 19.10.2021

Yayın Tarihi/Published 17.11.2021

\section{$\ddot{O}_{z}$}

Medya, iletileri ve göstergeleri okur, izleyici ve dinleyicilere ileten bir ortam mekanizması olarak kamuoyuna enformasyon sağlayan bir kaynaktır. Kamuoyu eğlenmek, bilgilenmek, inanç ve değerleri öğrenmek için medyaya bağımlı durumdadır. Medyanın bu gücünün farkında olan büyük sermaye sahipleri çeşitli imtiyazlar elde edebilmek ve toplumda saygin bir pozisyona yükselebilmek için medya sektörüne yönelmektedir. Yaşanan bu yoğun güç gösterisine maruz kalan medya tekelleşen ve holdingleşen bir ortama dönüşmüştür. Herman ve Chomsky 1993 yılında yayımladıkları 'Medya Gerçeği' adlı eserde Propaganda Modeli isimli bir yapı ortaya koymuştur. Herman ve Chomsy'nin ortaya koyduğu bu teorinin temel bileşenleri haber süzgeçleridir. 5 süzgeçten oluşan bu sistemin ilki kitle medyasının büyüklüğü, mülkiyeti ve kar yönelimli olmasıdır. Çalışma bu süzgeç üzerinden tekelleşme ve Türk medyasındaki tekelleşme olgusunun değerlendirilmesi üzerine odaklanmıştır. Türkiye'de özellikle 1980'lerden itibaren temel ekonomik politika olarak benimsenen liberal görüş basın üzerinde de ciddi değişimleri beraberinde getirmiştir. Daha önceki süreçlerde gazeteci kişiler veya gazetecilik kökenli ailelerin yönettiği basın sektörü artık büyük sermaye sahiplerinin eline geçmiş ve bu mecra tekelleşme trendi içerisine girmiştir. Bu çalışmada öncelikle Herman ve Chomsky'nin Propaganda Modeli tanımlanacak ardından, tekelleşme kavramı ve Türk medyasının tekelleşme süreci anlatılıp, gelişmelerin sektör üzerindeki etkileri irdelenecektir.

Anahtar Kelimeler: Propaganda Modeli, Tekelleşme, Türk medyasi.

Kaynak gösterme / To cite this article: Çakmak, M. (2021). Herman ve Chomsky'nin Propaganda Modeli Süzgeci Olan Kitle Medyasının Büyüklüğü ve Kar Anlayışı Üzerinden Tekelleşme ve Türk Medyasının Tekelleşmesinin İncelenmesi. The Journal of Communication and Social Studies, 1(1), 46-61. 


\title{
The Size of The Mass Media As The Propaganda Model Filter and The Examination of The Monopolization of The Turkish Media on Herman and Chomsky's Understanding of Profit
}

\author{
Murat ÇAKMAK*
}

* Phd Student, Süleyman Demirel University,

murat.cakmakk@yahoo.com Orcid ID: 0000-0002-1727-9314

Gönderilme/ Received 27.09.2021

Kabul Tarihi/ Accepted 19.10.2021

Yayın Tarihi/Published 17.11.2021

\begin{abstract}
Media is a source that gives information to people as an ambient temperature that transmits messages and aids people. The public complain to the media for entertainment, information, beliefs and values. A family option that can be chosen for large-scale people who can read that of the media. In this event, the remaining media is evolving towards monopoly. The use of the Propaganda Model in Herman and Chomsky's 1993 book, Media Truth. According to Herman and Chomsy, the main support in this theory is news filters. This sieve is first of all mass media high, each and wide in terms of profit. The study did not focus on monopolization and the evaluation of the phenomenon of monopolization in Turkey when viewed through this filter. In Turkey, especially since the $1980 \mathrm{~s}$, believers on the liberal view are widely used as a basic economic. It has been in a monopoly trend in the sector, with more people in person or while it was registered, from the management of families, and recently from large enterprises. In this study, first of all, the Herman and Chomsky Propaganda Model will be defined, the concept of monopolization and the process of the Turkish media will be explained and discussed on the targeted sector.
\end{abstract}

Keywords: Propaganda Model, Monopolization, Turkish media. 


\section{Giriş}

Herman ve Chomsky'nin ortaya koyduğu Propaganda Modeli kendi içerisinde birbirini tamamlayan beş farklı süzgece sahip bir teoridir. Model medya üzerindeki servet ve güç dengesizliğinin haber seçimlerindeki kanaatlerine odaklanmaktadır. Medya kuruluşları kamuoyuna sunulacak haberlerin üretilmesi ve yayınlanması olarak ifade edilen editoryal süreç artık çalışanların elinde olmaktan ziyade medya patronlarının elindedir. Bu kişilerin sektöre girmesi ile kabuk değiştiren medya artık tekelleşmiş bir alana dönüşmüştür. Çalışma Propaganda Modeli’nin ilk süzgeci olan Kitle medyasının büyüklüğü, mülkiyeti ve kar yönelimli oluşu yani tekelleşmesini temel almaktadır.

Türkiye 1980'li yıllardan itibaren siyasi konjonktürün devletçi ekonomi politikaları yerine artık dış dünyaya açık liberal görüşü benimsemeye başlaması ile birlikte toplumun hemen hemen her alanında bu iktisadi düşüncenin etkisini hissetmeye başlamıştır. Bu değişimlerin gözlemlendiği alanların başında da medya sektörü gelmektedir. Dönemin başat kitle iletişim aracı olan gazetelerin satın alınması ile başlayan tekelleşme süreci ilerleyen yıllarda televizyonların da satın alınmasını beraberinde getirmiştir. Yine 1990'lı yıllardan sonra kurulan özel tv ve radyo kanalları, yeni gazete ve dergileri bünyelerine katan medya patronları işletmelerine artık medya grubu ismini vermeye başlamıştır. Sermaye sahiplerinin güç gösterisinin yaşandığı medya artık belirli kişilerin elinde yönetilen bir alan haline dönüşmüştür.

İçinde bulunulan bu dönemde hemen hemen bütün yayın kuruluşlarının bir medya grubunun şemsiyesi altında faaliyetlerine devam ettiği görülmektedir. $\mathrm{Bu}$ durumun varlığı sektörde tekelleşme olgusunun var olduğunun büyük bir ispatı olarak karşımıza çıkmaktadır. Yaşanan bu gelişme sektöre yeni girmek isteyen işletmelere büyük bir engel teşkil etmektedir. Bu durum ise medyada farklılaşmanın önüne geçerken medya patronlarının aynı görüşlerinin farklı iletişim ortamlarında yeniden ve sürekli olarak tekrarlanmasına yol açmaktadır. Böylece egemen görüşler medyada tekrar edilip kitlelerin zihnine yerleştirilirken, farklı, muhalif ve marjinal görüşlerin medyada yer alamamasına ortam hazirlamaktadır.

Bu çalışmada öncelikle Herman ve Chomsky'nin Propaganda Modeli temel süzgeçleri ele alınmıştır. Daha sonra teorinin birinci süzgeci olan kitle medyasının büyüklüğü, mülkiyeti ve kar yönelimli oluşunun tekelleşmeye nasıl evrildiği ele alınıp, tekelleşme kavramı ve Türk medyasında tekelleşen farklı medya grupları ayrıntılı olarak incelenmiştir. Son olarak ise tekelleşmenin medya sektörü üzerinde yarattığı olumsuzlukların neler olduğuna değinilmiştir. Sonuç olarak ise Herman ve Chomsky'nin Propaganda Modeli'nin ilk aşamasının medya sektörü üzerinde tekelleşmeye yol açtığı sonucu elde edilmiştir.

\section{Herman ve Chomsky'nin Propaganda Modeli}

Herman ve Chomsky'e göre (Chomsky, 1993, s. 9) kitle iletişim araçları halka imgeler ve mesajlar ulaştırır. Kitle iletişim araçlarının temel fonksiyonları bilgilendirmek, eğlendirmek ve halka toplumun kurumsal yapısıyla birleştirecek, inançları ve davranış biçimleri hakkında kamuoyuna enformasyon sunmaktır. 
Dünya servetinin belirli bir kesimin elinde toplandığı dünya düzeninde bu ancak sistematik ve güçlü bir propagandayla gerçekleştirilebilir. Herman ve Chomsky bu sürecin nasıl işlediğini ve hangi safhalardan oluştuğunu göstermek için bir propaganda modeli oluşturmuşlardı. Bu süzgeçler;

1) Kitle medyasının büyüklüğü, mülkiyeti ve kar yönelimli oluşu,

2) İş yapmak için reklam verenler süzgeci,

3) Medyanın haber kaynakları süzgeci,

4) Tepki ve yaptırımcı kurumlar süzgeci,

5) Bir denetim mekanizması olarak anti-komünizm süzgecidir (Herman ve Chomsky, 2006, s. 72).

Birinci süzgeç: Kitle Medyasının Büyüklüğü, Mülkiyet ve Kar Yönelimli Oluşu: Kitle medyası var olabilmek için belirli bir sermaye ortaya koyması gerekmektedir. $\mathrm{Bu}$ şirketler piyasadan büyük kar elde etmek isteyen zengin kişiler veya bu kişilerin belirlediği yöneticilerden oluşmaktadır. Yöneticiler veya sermaye sahipleri kendi çıkarları doğrultusunda medyayı yönetirken, farklı sektörlerde yatırımları bulunan medya patronları güçlerini şirketleri üzerinde kullanarak daha da güçlenmesini sağlamaktadır. Piyasada bulunan mevcut tüm şirketler kendi aralarında, bankalar ve hükümet ile ilişkilerinde birbirleri ile sürekli olarak dirsek temasında bulunurken, bu birlikteliğin altında yatan temel dinamik ise bütünleşen ortak çıkarlardır.

19.yüzyıldan itibaren teknolojik gelişmeler ve bu duruma ek olarak gazete sahiplerinin daha geniş kitlelere seslenme arzusu basının endüstrileşmesine yol açmıştır. Endüstrileşme sahiplerin elde edebilecekleri kar miktarını maksimize ederken, kurulacak gazeteler için daha fazla para harcanmasını ve gazetelerin tiraj sayılarını yükselmesi zorunluluğunu beraberinde getirmiştir. Örneğin İngiltere'de 1837 yılında kar elde edebilecek ulusal gazetenin toplam maliyeti bin Sterlin'in altındayken bu rakam 1867'de 50.000 Sterline, 1918 yılında ise iki milyon Sterline yükselmiştir (Curran ve Seaton, 1985, s. 24).

Medya sektörünün sahip olduğu etki ve finanse edilme zorunluluğu medyada tekelleşmeyi beraberinde getirmiştir. Medya patronları bankacılık, finans, enerji, hizmet, turizm, otomotiv, sanayi, ticaret, tekstil, madencilik gibi pek çok alanda faaliyet göstermektedir (Bulunmaz, 2011, s. 239). Bu kişiler aynı zamanda medya yatırımlarını haber ajansları, kitap, dergi, reklam ajansları, yapım ve prodüksiyon gibi alanlara yönelerek sektörle ilişkili faaliyetleri çeşitlendirmiş ve Nail Güreli'nin ifadesiyle artık sektörün patronları birer medyatik olmuştur. (Güreli, 2004, s. 36) Böylece medyanın tüm güç ve hakimiyeti tek elde toplanmış tekelleşmenin daha da sert şekilde uygulanması amaçlanmıştır. Makalenin temel çalışma teması bu konu olması hasabiyle ilerleyen sayfalarda bu kavrama ayrıntılı olarak yer verilecektir.

İkinci süzgeç: İş Yapmak İçin Reklamcılık Ruhsatı: Serbest piyasa ekonomilerinde Herman ve Chomsky (2006, s. 84)'e göre reklam verenler medya alanında bir anlamda ruhsat verenlerdir. Çünkü medya reklam gelirleri ile büyük oranda ayakta kalmaktadır. Reklamlar kitle medyasının oluşmasındaki temel taşlardan birisi olarak karşımıza çıkmaktadır. Çünkü reklam gelirleri ile medya 
maliyetlerini düşürüp herkesin alabileceği bir mecra halini almıştır. Günümüzde reklamlar medya kuruluşlarını ayakta tutan temel gelir kalemini oluştururken, bu imkandan faydalanan işletmeler rakipleri karşısında güçlü konuma erişir ve onları zayıflatma şansını ele geçirir. Reklamlardan gerektiği şekilde faydalanamayan kuruluşlar ise pazar paylarını kaybederek piyasadan çekilmek zorunda bırakılmaktadır (Bagdikian, 1987, s. 121).

Reklam veren kuruluşlar medya üzerinde etkili bir güçtür. Zira bu kişiler programları satın alırlar ve parasını öderler; onlar medyaya parasal destek sağlayan "patronlardır." Bu şekilde, medya şirketleri reklam veren kuruluşlarla zorunlu olarak programlarının reklam veren kuruluşların ihtiyacına cevap verecek şekilde kendi içeriklerini oluşturmaktadır. Çünkü eğer medya başarılı olmak istiyorsa onların istek ve taleplerini yerine getirmelidir (Turow, 1984, s. 52). Reklam almadan yani temel ekonomik getirisi olmayan medya kuruluşlarının ayakta durma ihtimalleri çok düşüktür.

Üçüncü süzgeç: Kitle Medyasının Haber Kaynakları: Medya kuruluşları çok iş yapıp bunun karşılığında minimum harcama yapmayı sıkça kullanmaktadır. Giderleri azaltmak için yapılması gereken temel şey ise haber masraflarını azaltma gerekliliğidir. Bu sebepten dolayı medya kuruluşları en kısa ve kolay yoldan haber elde etmeye çalışmaktadır (Herman ve Chomsky, 1999, s. 59). Medya bu noktada haber kaynakları bağlamında hem devlete hem de şirketlere bağımlıdır. Çünkü birçok rutin haber hükümet ve şirketlerden çıkar ve bu haberler hükümet ve şirket çalışanları tarafindan basına sunulmaktadır. Aldığı haberleri paylaşma eğiliminde olan medya onların görüşlerini servis eder ya da aktarır hale dönüşmektedir. (Shoemaker ve Reese, 2014, s. 111).

Medya kuruluşlarının günlük haber ihtiyaçları ve zorunlu olarak doldurmaları gereken haber programı takvimleri bulunurken, bu takvime uymak için toplanması gereken haberleri elde etmesi için gerekli elemana ve araca sahip olmaları gerekmektedir. Medya gündemini kamuoyu ile paylaşma gerekliliği bulunan medya devlet organlarından anlı haber alabileceği yerlere yönelmektedir. Bu tür habercilik faaliyetlerine örnek gösterilebilecek Meclis, Bakanlıklar, Emniyet müdürlükleri gibi yerler kilit noktalarıdır. Şirketler ve meslek grupları da haber değeri taşıdığı kabul edilen hikâyelerin düzenli ve güvenilir bir şekilde sağlandığı yerlerdir. Resmi kaynakların "objektif" haber ileticisi olduğu iddiası onlardan daha fazla yararlanılmasına yol açmaktadır. Güvenilir olduğu düşünülen bir haber kaynağından bilgi almak araştırma masraflarını ciddi oranda azaltırken, güvenilirliği eleştiriye yol açabilecek kaynaktan alınan haberler üzerinde daha detaylı bir araştırmayı gerekli kılmakta, bu durum ise başka bir masrafları beraberinde getirecektir.

Dördüncü süzgeç: Tepki Üretimi ve Zorlayıcılar: Bu süzgeç bir anlamda olumsuz eleştiri merkezlerine bir gönderme yapar. Bu olumsuz eleştiriciler de görüşlerini aktarmak için medyaya ihtiyaç duyarlar. Bir anlamda üçüncü süzgecin işlevini de gerçekleştirip, medyaya kaynak sağlarlar. Tepki ortaya koyma yolları mektup, telefon, telgraf, dilekçe, dava açma, kongrede, mecliste konuşma yapma ya da kongreye, meclise yasa tasarısı sunma gibi yöntemlerle gerçekleştirilebilir. Tepki yaratan odaklar birbirlerinin gücüne güç katar ve siyasi otoritenin haber yönlendirme faaliyetlerindeki egemenliği pekiştirirler. Bu bir 
silsile şeklinde gelişir etki tepkiyi, tepkide tekrar etkiyi yaratır. Hükümet, başlıca tepki üretme odaklarından biridir. Kurulu düzenin çizgisinden sapan medyayı düzenli saldırı, tehdit ve düzeltmeler yoluyla hizaya sokmaya çalışır (Herman ve Chomsky, 1993, s. 75). Çeşitli yaptırımlar ve tehditler sonucu muhalif medya yıpratılır ve sonu hazırlanır. Çeşitli güç odaklarına ve kitlelere hedef gösterilen medya kuruluşları, bu durum karşısında çaresiz kalmakta ve çoğu kez de kendini savunamamaktadır (Özer, 2019 , s.28).

Beşinci süzgeç: Bir Denetim Mekanizması Olarak Anti-Komünizm: İkinci Dünya Savaşı sonrasından Sovyet Sosyalist Cumhuriyetler Birliği'nin 1991'de dağılmasına kadar olan süreçte Batı dünyası kominizim tehlikesi ile yüzleşmiştir. Kominizim, başta mülkiyet sahiplerinin sınıfsal konum ve üstün statüleri için risk teşkil etmesinden dolayı onların büyük çekincelerinin kaynağını oluşturmuştur. (Herman ve Chomsky, 1993, s. 82). Egemen siniflar kominizim tehlikesini kullanarak, medya çalışanlarını ve sahiplerini tehdit etmekte ve onları vatan haini olmakla itham etmekteydi. Bir kişi ne kadar haklı olursa olsun komünist ise o kişinin söyledikleri ve yazdıkları kesinlikle yanlıştır ve toplumun zararınadır. Komünist olarak fişlenen yazarlar toplum tarafından dışlanmakta ve eleştirilmektedir. Aynı zamanda anti kominizim solun ve iş̧̧i hareketlerinin bölünmesine yardımı olup siyasi bir denetim mekanizması işlevini görürken, bölünen ve dışlanan sol ise güçsüzleşip ve hâkim sınıflar karşısında çaresiz bir konuma gelmektedir (Herman ve Chomsky, 2006, s. 99).

Medya bir haber yaparken yukarıda ele alınan beş haber eleme süzgecini göz önüne alarak haber yapar. Haber yapılırken medyanın patronu gözetilerek haber yapılır ya da haber, patronu koruyacak şekilde kurgulanır. Yine aynı şekilde bir haber yapılırken, medyanın en önemli gelir kaynağı olan reklam verenlerin talep ve beklentilerine göre haber oluşturulmaktadır. Çünkü reklam verenleri küstürecek bir haber kurumun gelir kalemlerinde azalmaya neden olacaktır. $\mathrm{Bu}$ sadece haberle sinırlı düşünülmemeli, elbette medya içerisinde yer alan her türlü yayın bu süzgeçlerden geçerek ekranlarımıza ya da sayfalarımıza düşmektedir (Güngör, 2013, s. 141).

\section{Tekelleşme ve Basının Tekelleşmesi}

Basının tekelleşmesini incelemeden önce tekelleşmenin ne olduğunu açıklamak gerekmektedir. Tekelleşme 'toplumsal yapıların herhangi bir alanındaki süreç ya da aşamasında yönetimin tek bir güç yapısı tarafindan denetim altına alınmasıdır (Özgüven, 1991, s. 280). Daha kapsamlı bir tanıma göre ise 'bir mal veya hizmetin üretim, dağıtım ve satım aşamalarının tek elde olduğu, piyasa için gerekli arzın tek bir güç tarafindan yönetildiği piyasa türüdür (Demir ve Acar, 1997, s. 287). Medya sektöründe yaşanan tekelleşme eğiliminin altında yatan temel dinamiklerin sektörün değişen doğası ve medya şirketlerinin büyüme eğilimleri olduğu söylenebilir (Bayram, 2013, s. 246). Aslında tekel ve tekelleşme ifadeleri her ne kadar ekonomi ile ilgili bir kavram olarak görünüyor olsa da, bu iki kavram Dünya üzerindeki mevcut tüm yapılanmaları ve dolayısıyla da medyayı da etkilemektedir. Medyanın tekelleşmesi büyük sermaye sahiplerinin medyanın ilk aracı olan gazeteleri satın alması ile başlamıştır. Medyanın sahip olduğu güç ve etkinin farkında olan iş adamları alana yatırım 
yaparak prestijlerini arttırmışlardır. $\mathrm{Bu}$ iş insanlarının amaçları şu şekilde siralanabilir (Kuyucu, 2013, s. 149);

- Toplumsal üstünlük

- Kamuoyu hizmeti

- Kamuoyunu etkilemek ve yönlendirmek

- Rekabet avantajını ele geçirmek

- Rant sağlamak

- Siyasi destek

Medyada görülen tekelleşme biçimlerini yatay, dikey ve çapraz tekelleşme olarak üç grupta toplamak mümkündür. Tokgöz'e göre yatay tekelleşme, medya sektöründe görülen tekelleşmenin en yaygın olanıdır (Tokgöz, 2008, s. 142). Dünyada olduğu kadar Türkiye'de de yatay tekelleşme medya sektöründe çok yaygındır. Yayın yaşamlarını sürdürmekte ekonomik koşullar nedeniyle güçlük çekme, basında yatay tekelleşmenin oluşmasını beraberinde getiren bir olgu olarak karşımıza çıkmaktadır (Bulunmaz, 2011, s. 243). Yatay tekelleşme ile birlikte, kendi yazı işlerine sahip gazete sayısında azalma görülmektedir. Dikey tekelleşme ise bir kuruluş faaliyet gösterdiği iş alanının bütün aşamalarını sağlayabildiği tek yapı kurmuşsa bu dikey bütünleşmedir (Şeker, 2018, s. 115). Dikey tekelleşme kendi içerisinde farklı şekillerde gerçekleşmektedir. Bunlardan ilkine göre birden çok yayın organın sahipliği tek kişinin eline geçerken yazı işlerinde herhangi bir değişikliğe gitmemektedir. Dikey tekelleşmenin ikinci uygulamasına göre ise mevcut çalışanların büyük bir kısmı veya tamamı işten çıkarılır ve oluşturulan içerikler eski özelliklerinden ciddi anlamda uzaklaşmaktadır. Bu sürecin devamında ise benzer özellikler gösteren yayın organları ortaya çıkmaktadır. Dikey tekelleşmenin üçüncü şeklinde ise gereken kağıdın üretimi, haberin üretimi, yayını ve dağıtımı gibi birbirini izleyen süreçler bulunmaktadır (Tokgöz, 1994, s. 29). Çapraz tekelleşme ise aynı sermaye sahipliğinin farklı medya alanlarında ve bunun dışında da diğer iş alanlarında mülkiyet sahipliği çapraz tekelleşme olarak adlandırılmaktadır (Avşar, 2004, s. 90). Çapraz tekelleşmede daha önceki süreçte tek bir mecrada etkisi hissedilen kuruluşların sektörün ilişkili alanlarında faaliyetler bulunması ile gerçekleşmektedir. Örneğin sadece basılı medyada var olan işletmeler ilerleyen dönemlerde görsel, işitsel alanlarda da var olmaktadır. Yavuz Bayram’a göre çapraz tekelleşme günümüzde daha da derinleşerek yeni bir boyut kazanmış ve ultra çapraz tekelleşme adını verdiği bir yapının ortaya çıktığından bahsetmektedir (Bayram, 2013, s. 248). Büyük sermaye sahiplerinin medya sektörüne yaptıkları yatırım dışında sanayi, tarım, sanayi, ticaret, otomotiv, tekstil gibi farklı alanlarda çalışmalar yürütmesi ultra çapraz tekelleşme olarak adlandırılmaktadır (Yöyen, 2007, s. 65). Türkiye'de mevcut olan medya gruplarının ultra çapraz tekelleşmenin tezahürü olduğu açıkça görülmektedir.

Basında tekelleşmenin ortaya çıkmasında farklı şekillerde ortaya çıkmaktadır;

1-Yazı işleri birbirinden ayrı, birden fazla yayın organında yayımlanan içerikleri aynı iletilerin büyük sermaye topluluğunun denetiminde olması 


\section{2-Yazı işleri tek elden yürütülen yayınlar topluluğu}

\section{3-Farklı yayın türlerinin aynı sermaye grubu tarafından neşredilmesi}

4-Büyük sermaye gruplarının yazılı, görsel ve işitsel alanlarda birden fazla etkinlik yürütmesi şeklinde gerçekleşmektedir (Özek, 1999, s. 549).

\section{Türk Medyasında Tekelleşme Süreci ve Medya Grupları}

Türk medyası açısından tekelleşme sürecinin kısa bir özetini vermek gerekirse Türkiye'de medya denilen mecra ilk olarak 1 Mayıs 1964'te tüzel bir kişiliğe sahip kuruluş olan Türkiye Radyo ve Televizyon Kurumu'dur (TRT). TRT 1980'li yılların sonuna kadar medyada tek söz sahibi iken rekabete dayalı sektör temsilcilerinin medyaya yönelmesiyle Türk medyasının çehresi değişmeye başlamasına yol açmıştır. 1990'lı yıllarda Magic Box televizyon kanalının kurulması ile başlayan yenileşme furyası hızla devam ederek 2000'li yıllarda kitle iletişim araçlarının belirli kişiler ve belirli holdinglerin elinde toplanması ile devam etmiştir.

Basın organları başlangıçta, sosyal ve siyasal nitelikli bilgileri kitlelere ulaştıran iletişim araçları olarak işlev görmüşlerdir. Yakın tarih ve Türkiye örneği üzerinden ele alındığında basın, 1950-1980 yılları arasında fikir gazeteciliği altında faaliyet göstermiş ve mesleği gazetecilik olmayan kişiler tarafından yönetilmiştir. 1980 sonrasında, ise büyük iş adamlarının sektöre dahil olması sonucu yapısal ve ideolojik değişimler yaşanmıştır. Türk basınında meslek dışından ilk katılım, 1948 yılında Sefa Kılıçoğlu'nun Yeni Sabah gazetesini satın almasıyla başlamış olsa da $1970^{\mathrm{e}} \mathrm{li}$ yılların sonuna kadar basın organları gazetecilik mesleğinden gelen aileler tarafından yönetilmeye devam etmiştir (Gürel ve Çetin, 2020, s. 117). 1979 yılında Aydın Doğan'ın Milliyet gazetesini satın almasıyla birlikte sektör dışından ikinci katılım gerçekleşmiştir ve basın sektöründeki sahiplik yapısı hızlı bir şekilde büyük sermaye sahibi olan iş adamlarının yönetimine geçmeye başlamıştır (Bulunmaz, 2011, s. 241). 1980'li yıllarda dünyadaki ekonomik ve toplumsal değişimlere koşut olarak neoliberalizmin yükselen ivmesi, basın sektörünü de etkilemiştir. 24 Ocak 1980 günü alınan kararla Türk basın sektörü için yaşanacak değişimlerin kilometre taşını oluşturmuştur. Karar kapsamında devletin gazete kâğıtlarına verdiği desteğin kaldırılması ile küçük işletmeler piyasadan çekilirken yerlerine büyük sermaye sahipleri geçmiştir. (Kuyucu, 2013, s. 148). Bu değişimlerle birlikte medya sektöründeki sahiplik yapısı, medya dışı faaliyet gösteren büyük sermayenin sektöre girişini hızlandırmıştır. Farklı sektörlerde yer alan holdinglere dahil olarak büyüme gösteren medya işletmelerinin sayısı giderek artış göstermiştir (Kadıoğlu, 2018, s. 105). Basın kuruluşları, 1980’ler ile birlikte kurumsallaşma sürecine girmiştir. Büyük sermaye sahibi iş adamlarının bu alanlara yatırım yapmaya başlaması ile birlikte kâr odaklı bir düşünce yapısı, sektöre hâkim olmuştur. Nitekim hızlanan kurumsallaşma sürecine koşut olarak gazetecilik kökenli aileler, sektörden ayrılmış ve sektörün tüketim, dağıtım ve kontrol yapısı büyük oranda iş adamlarının eline geçmiştir. Bu durum ise sermaye sahiplerinin, kendi çıkarlarını temsil eden ve kârı merkeze alan içerik üretmelerine neden olmuştur (Yaylagül, 2019, s. 407). 1980'de başlayan ekonomik ve yapısal dönüşüm, sonraki yıllarda da devam etmiştir. 1980 ve 1990 yılları arasında Türkiye'de büyük sermaye sahiplerinin medyanın bütün alanlarında 
hâkim olduğu, sınırlandırılmalara yönelik tüm kuralların kaldırıldığı, medyanın özelleştirilmesinin desteklendiği, bankacılık ve finans alanında yatırımları olan iş adamlarının bu alanda yoğunlaştığ kollarında yatırımları bulunan büyük sermaye sahiplerinin medya sektöründe yer almaya başlaması, basın organlarının haber ve bilgi verme işlevlerinin geri plana atılarak kâr amacı güden işletmelere doğru evrilmesine neden olmuştur.

Günümüzde de aynı koşulların devam ettiği sektörde isimler değişiyor olsa da holdingleşme devam etmektedir. Türk medyası için ilk satın alma Asil Nadir tarafindan başlamış iken sektörün holdingleşen ilk ismi Aydın Doğan olmuştur (Bulunmaz, 2011, s.241). Doğan ilk olarak 1979 yılında Milliyet gazetesi ile sektöre giriş yaparken, devamında ise 1994 senesinde Hürriyet gazetesini bünyesine katarak medya dünyasının ilk tekelleşen ismi olmuştur. Aydın Doğan'ı Dinç Bilgin, Enver Ören, Cem Uzan ve Erol Aksoy gibi isimler takip etmiş ve Türk medyası büyük holdinglerin gövde gösterisinin yaşandığı bir ortam halini almıştır. Medya patronlarının gazetelerini okutabilmek için başvurdukları ilk yöntem promosyon uygulamaları olmuştur (Bayram, 2013, s. 251). Promosyon uygulamasının ilk örneği Hürriyet gazetesinin kurucusu Sedat Simavi'nin Karagöz gazetesinin 13 Mayıs 1939 tarihli sayısında düzenlediği 'İkinci Dünya Savaşı'nın yaşanması halinde kazananı kim olur?' başlıklı ödüllü bir anket olmuştur (Çetin ve Tüzer, 2017, s. 207). Kamuoyunun savaşa karşı bakışını ölçmek amacıyla düzenlenen bu kampanyanın ardından medyanın tekelleşmesiyle ile promosyon hareketleri de değişmiş, gazeteler mali değeri bulunan ödüller vermeye başlamıştır. Bu promosyonlar kapsamında beyaz eşya, saat, mutfak eşyaları, otomobil, arsa, bisiklet, ev, cep telefonu, müzik seti hatta hac ve umre organizasyonları için bile kampanyalar düzenlenmiştir (Bayram, 2013, s. 251). Promosyon kapsamında tüketiciyle yakınlaşma amacı taşıyan hediyeler düşük fiyatlı, düşük kaliteli ve pazarı bulunmayan ürünler olduğu için kısa sürede arızalanmalara neden olmuş bu durum ise okurlar arasında gazeteye karşı olumsuz düşüncelerin beslemesine yol açmıştır. Aydın Doğan'ın sahip olduğu Doğan Yayın Holding'in teşebbüslerini 2018 yılında Erdoğan Demirören'e satması ile isim değiştirerek Demirören Medya Grubu adını alırken bu şirket dışında Türk medyası ağırlıklı olarak, Turkuaz Medya Grubu, Albayrak Grubu, Ciner Medya Grubu ve Doğuş Medya Grubu'nun patronajı altında bulunmaktadır (Bulunmaz, 2011, s. 239).

Demirören Medya Grubu 1980'li yıllardan sonra medyada meydana gelen şirketleşme trendi Hürriyet Gazetesi'ni etkilemiş ve gazete Erol Aksoy, Dinç Bilgin ve Haldun Simavi’nin ortaklığına girmiştir. 1994 yılına gelindiğinde şirketleşmeden holdingleşen bir yapıya bürünen Hürriyet Gazetesi'nin hisselerinin \%70'i Doğan Holding'e satılmıştır. 2018 yılında ise Doğan Holding Hürriyet Gazetesi'nin de içerisinde yer aldığı Doğan Medya Grubu'nu 1.2 Milyar dolar bedelle Demirören Grubu'na satmıştır (www.t24.com.tr, 2018). Demirören Medya Grubu faaliyetlerini Yazılı Medya, Görsel- İşitsel Medya, Basım Yayıncılık ve Haber Ajansları şeklinde oluşurken bu gruplar kendi içlerinde pek çok işletmeyi barındırmaktadır. Yazılı medya altında Hürriyet, Milliyet, Posta, Daily News, Fanatik gibi gazetelere sahip olduğu görülmektedir. Bu 6 gazete 12-18 Nisan 2021 tarihleri arasındaki süreçte toplam tirajın 1.517.284 olduğu Türkiye'de günlük ortalama 481.777 tiraja sahiptir (http://gazetetirajlari.com/). 
Elde edilen ortalamalardan hareketle Demirören Medya Grubu toplam tirajda \%31,49 gibi görece olarak yüksek bir tiraj ortalamasına sahiptir. Ayrıca yine bu verilerden yola çıkıldığında Türkiye'de satılan her üç gazeteden birinin Demirören Medya Grubuna ait olduğu görülmektedir. Yazılı medyaya ek olarak dijital medya kanallarına sahiptir. Gazetelerin internet sitelerine ek olarak yine gazetecilik amacıyla spor, ekonomi, magazin, gündelik hayat ve kadınlara yönelik bilgilerin yer aldığı kurum bünyesine bağlı internet siteleri bulunmaktadır. Ekonomi alanında Big Para, Hurriyet Oto, Uzman Para, spor alanında Skorer, Skorer Tv, Spor Arena, magazin alanında mahmure.com, günlük yaşam ve kadınlara yönelik olarakta Pembenar ve Molatik gibi portallar bulunmaktadır. Medya sektörünün temel taşı olarak gösterebileceğimiz görsel ve işitsel medya bağlamında da şirketin ciddi yatırımlarının var olduğu görülmektedir. Televizyon kanalları olarak; Kanal D, CNN Türk, teve2, Euro D mevcut iken işitsel medyada ise Dream Radyo, Dream Türk, Radyo D, CNN Türk Radyo işletmeye bağlı olarak yayın hayatını sürdürmektedir. Görsel işitsel medyada televizyon ve radyo kanallarına ek olarak D Smart isimli dijital platforma sahiptir. Kullanicilar Türksat üzerinden yayın yapan tüm kanallara erişmesine ek olarak belirli bir bedel karşılığında çeşitli tematik yayınları izleme imkanına sahip olmaktadır. Üretilen bilgilerin basılması hususunda da Demirören Printing Center'a ve mevcut köşe yazılarının kitaplaştırılması veya promosyon olarak verilecek ürünlerin basılması hususunda da şirket bünyesinde yer alan Hürriyet Kitap kullanılmaktadır. 2018 yılında Aydın Doğan'ın mevcut tüm haklarını Erdoğan Demirören'e devretmesinden önce Türk medyasında başat haber ajanslarından biri olan Doğan Haber Ajansı yaşanan el değiştirme ile Demirören Haber Ajansı adını almıştır. Ajans kurumsal internet sitesinde günlük olarak kamuoyu ile 1000 fotoğraf, 300 görüntü ve 300 haber içeriği oluşturup sunduğunu ifade etmektedir. Demirören Medya Grubu sahip olduğu mevcut imkanlar ve büyük medya yatırımları ile Türk medyasında lider konumda bulunmaktadır.

Türk medyasında ikinci büyük güç olarak gösterilebilecek grup ise Çalık Holding'e bağlı Turkuvaz Medya'dır. Çalık Holding 2007 yılının Aralık ayında TMSF'nin elinde bulunan ve kamuoyunda Sabah-ATV grubu olarak bilinen grubu tüm iştirakleriyle birlikte satın alarak medya dünyasına giriş yapmıştır. Turkuvaz Medya günümüzde faaliyetlerini yazllı medya, görsel işitsel medya ve basılı medya üzerinden sürdürmektedir. Yazılı medya olarak Sabah, Takvim, Yeni Asır, Daily Sabah ve Fotomaç gazetelerinin mülkiyeti Turkuaz Medya'nın elindedir. $\mathrm{Bu} 5$ gazete 12-18 Nisan 2021 tarihleri arasındaki süreçte toplam tirajın 1.517.284 olduğu Türkiye'de günlük ortalama 368.322 tiraja sahiptir. Toplam gazeteler üzerinden yapılan oransal dağılımda ise \%25'lik paya sahiptir. Gazetecilik faaliyetlerine ek olarak Turkuvaz Medya eski dönemlerle kıyaslandığında daha az tercih edilen dergicilik faaliyetlerine diğer medya gruplarına göre daha yoğun şekilde devam ettiği görülmektedir. Bebeğim ve Biz, China Today, Cosmopolitan, Cosmopolitan Bride, Esquire, Forbes Türkiye, GQ Türkiye, Home Art, House Beatiful, Lacivert, Oto Haber, Para, Sofra, Şamdan Plus, Vogue Türkiye, Minika Çocuk, GO Minika ve Kukuli Dergileri yayın hayatlarını sürdürmektedir. Dergilerin bu denli farklı yelpazeden olmasına ek olarak çocuklara yönelik dergilerin varlığı dikkat çekici bir faktör olarak görülmektedir. Görsel medyada Atv, A Haber, A Spor, A News, A Para, A2, Vav Tv, Minika Çocuk, GO Minika gibi tv kanallarına sahip olmasına ek olarak işitsel 
medyada Radyo Turkuvaz, A Haber Radyo, A Spor Radyo mecralarının sahibi yine Turkuvaz Medya'dır. Görsel ve işitsel medyanın birlikte kullanıldığı sinema sektöründe ise Sinehane Prodüksiyon ile yapımcılık faaliyetlerinde yer almaktadır. Dergicilik çalışmalarına azami ölçüde ağırlık veren grup basım faaliyetlerini Turkuvaz Medya Basım kuruluşu ile karşılarken basılı ürünlerin dağıtım ve pazarlanmasını ise yine kendi bünyesinde bulunan Muhit Kitap, Sahi Kitap, D\&R, İdefix ve Prefix üzerinden gerçekleştirmektedir. Dijital medyada yeniasirilan.com, 7/24 Dinle internet siteleri vasitasıyla mecranın doğasına uygun çalışmalar yürütmektedir.

Türk medyasında bir diğer güç ise Albayrak Medya Grubu'dur. Albayrak Grubu, 1995 yılında Türkiye'nin en saygın gazetelerinden Yeni Şafak’ı bünyesine katarak medya sektörüne adım atmıştır. TVNET ise Albayrak Medya'nın 2007 yılında kurduğu televizyon kanalıdır. TVNET, Türkiye ve dünya gündemini 7 gün 24 saat kesintisiz şekilde ekranlara yansıtmaktadır. Dergi yayıncılığına 2012 yılında başlayan Albayrak Medya, aylık periyotlarda çıkan Derin Tarih, Nihayet, Z Raporu, Lokma, Cins, Skyroad, Bilge Çocuk ve Bilge Minik'in yanı sıra, iki aylık Post Öykü ve haftalık Gerçek Hayat dergileriyle sektörde yer almaktadır. 2013 yılından sonra dijital alanda yaptığı yatırımlarla dikkat çeken Albayrak Medya, Piri Medya markasıyla yenisafak.com, gzt.com (Arkitekt, Mecra, Zpor, Gazete Manşet, GZTMZT, Jurnalist) gibi takibi yüksek platformlarla birlikte, gruba ait tüm yayınların dijital iletişim süreçlerini yürütmektedir. 2018 yılından itibaren yayın hayatına adım atan Ketebe Yayınları ise, Albayrak Medya'nın kitap yayıncılığındaki markası olarak karşımıza çıkmaktadır. Albayrak Medya bünyesinde yayımlanan gazete, kitap ve dergilerin satış, pazarlama, abonelik ve dağıtım faaliyetlerini yürüten Birlikte Dağıtım ile mecraların reklam satışını gerçekleştiren Reklam Piri de grubun güçlü şirketleri olarak hizmet vermektedir.

Ciner Yayın Holding, bünyesinde birçok işletme barındıran Ciner Holding'in bir şirketidir ve medya alanında faaliyet göstermektedir. Ciner Yayın Holding 14 Eylül 2007 tarihinde kurulmuştur (http://www.cinergroup.com.tr). Türk medyasında hakim olan medya gruplarından birisi olarak kabul edilen Ciner Grubu'nun medya sektöründeki serüveni 2007 öncesine dayanmaktadır. Ciner Grubu'nun 2007 öncesindeki medya faaliyetleri Ciner Grubu adı altında değil, Merkez Medya Grubu adı altında gerçekleşmiş ve 2007 yılında TMSF tarafından el konulup satılması sonrası (Turkuvaz Medya Grubu'nun kontrolündeki medya varlıkları) Ciner Grubu, medya alanında varlığını sürdürmek adına Ciner Yayın Holdingi kurmuştur (Kılıçatan, 2011, s. 195).

Ciner Medya Grubu'da Demirören Medya Grubu ve Turkuvaz Medya gibi sektörün farklı alanlarında faaliyetlerini sürdürmektedir. Şirket basılı medyada 1 Mart 2009'dan 5 Temmuz 2018 tarihine kadar HaberTürk ile gazetecilik hususunda yer almıştır. Ciner Holding aldığı karar doğrultusunda çeşitli sebeplerden ötürü basılı medyadan çekilirken, bu tarihten itibaren ise dijital medyada yayın hayatına devam etmektedir. Ciner Holding basılı medyada yaşanan bu kapanmaya rağmen HT Hayat, HT Kulüp, HT Emlak, Bussiness HT dergilerinin basımına devam etmektedir. Basım işleri de yine holdingin başka bir işletmesi olan HaberTürk Matbaacılık tarafından gerçekleştirilmektedir. Görsel medyada televizyon alanında HaberTürk TV, Bloomberg HT, Show TV, Show 
Max, Show Türk kanalları mevcut iken prodüksiyon şirketi olarak ise C Yapım Filmcilik holdinge bağlı olarak çalışmaktadır.

Türk medyasında önemli bir diğer medya gücü Doğuş Yayın Grubu'dur. Doğuş Yayın Grubu ise, 1993 yılında Milliyet'in sahibi Aydın Doğan ile birlikte DTV Haber ve Görsel Yayıncılık A.Ş. adı altında Kanal D'ye iştirak ederek medya alanına giriş yapmıştır. Daha sonra Kanal D hisselerinin tamamını 1995'te Doğan grubuna devreden Doğuş Grubu, televizyon alanındaki en güçlü çıkışını ise 1999 yılında Cavit Çağlar'dan satın aldığı NTV ile yapmıştır. Çağlar'ın sahibi olduğu Nergis Holding'e bağlı olan "A Yapım Televizyon Programcılık A.Ş." ile Nergis (NTV) Haber Ajansı Reklam ve Tic. A.Ş. 1999 yılında Doğuş Grubu'na geçmiştir. Günümüzde Doğuş Yayın Grubu televizyon kanalı olarak NTV, Star ve Euro Star'a radyoda NTV Radyo, Kral Fm, Kral Pop Radyo'nun işletmecisidir. Ayrıca holding yüzlerce dizi ve filmi bir arada izleyiciye internet üzerinden ücretsiz şekilde sunan 'puhu tv' isimli platformunun da sahibidir.

Grupların medya dışındaki faaliyet alanları da oldukça çeşitlidir. Bu faaliyet alanları Tablo 1'de özetlenmiştir.

Tablo 1: Türkiye'deki Medya Grupları'nın Diğer Faaliyet Alanları

\begin{tabular}{|c|c|c|c|c|c|}
\hline $\begin{array}{ll}\text { Grup } & \text { ve } \\
\text { Sahibi } & \end{array}$ & Enerji & Sanayi & Turizm & İnşaat & Diğer \\
\hline $\begin{array}{l}\text { Demirören } \\
\text { Grubu } \\
\text { Erdoğan } \\
\text { Demirören }\end{array}$ & $\begin{array}{l}\text { Milangaz } \\
\text { Oto } \\
\text { Milangaz } \\
\text { Moil }\end{array}$ & 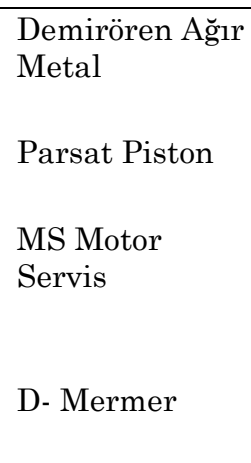 & $\begin{array}{l}\text { Kemer } \\
\text { County } \\
\text { Kemer } \\
\text { Country Club } \\
\text { Kemer } \\
\text { Country Hotel } \\
\text { Lidya Flats } \\
\text { Seyhan Park }\end{array}$ & Lidya Yapı & $\begin{array}{l}\text { Demirören AVM } \\
\text { İsletmeciliği } \\
\text { Zeyport Liman } \\
\text { İsletmeciliği } \\
\\
\text { Dolfen İskelesi } \\
\text { ATA Eğitim Kurumları }\end{array}$ \\
\hline $\begin{array}{l}\text { Çalık Grubu } \\
\text { Ahmet Çalık }\end{array}$ & $\begin{array}{l}\text { Çalık Enerji } \\
\text { Yeşilırmak } \\
\text { Elektrik } \\
\text { Dağıtım } \\
\text { Yeşilırmak } \\
\text { Elektrik } \\
\text { Perakende } \\
\text { Satış A.Ş } \\
\\
\text { Kosova Çalık } \\
\text { Limak } \\
\text { Energy } \\
\text { ARAS EDAŞ } \\
\text { ARAS EPAŞ }\end{array}$ & Çalık Denim & & GAP İnşaat & $\begin{array}{l}\text { Aktifbank } \\
\text { BKT Aravutluk } \\
\text { (Finans) } \\
\text { BKT Kosova (Finans) } \\
\text { ALB TELECOM } \\
\text { (Telekomünikasyon) } \\
\text { GAP Pazarlama }\end{array}$ \\
\hline Albayrak & & TÜMOSAN & Birun & Albayrak & Trabzon Port Liman \\
\hline
\end{tabular}




\begin{tabular}{|c|c|c|c|c|c|}
\hline $\begin{array}{l}\text { Grubu } \\
\text { Ahmet } \\
\text { Albayrak }\end{array}$ & & $\begin{array}{l}\text { Motor } \\
\text { Varaka Kağıt } \\
\text { Kademe Atık } \\
\text { Teknolojileri } \\
\text { TÜMOSAN } \\
\text { Döküm } \\
\text { Mezra Ziraat }\end{array}$ & $\begin{array}{l}\text { Kümbet Dağ } \\
\text { Evi } \\
\text { Platform } \\
\text { Turizm }\end{array}$ & İnşaat & $\begin{array}{l}\text { İşletmeciliği } \\
\text { Albil Merkezi Hizmetler } \\
\text { (Dijital Hizmetler) } \\
\text { Reklam Piri } \\
\text { (Reklamcılık } \\
\text { Hizmetleri) } \\
\text { Birlikte Dağıtım } \\
\text { (Lojistik Hizmetleri) }\end{array}$ \\
\hline $\begin{array}{l}\text { Ciner Grubu } \\
\text { (Turgay Ciner) }\end{array}$ & $\begin{array}{l}\text { Park Teknik } \\
\text { Park Elektrik } \\
\text { Silopi } \\
\text { Elektrik } \\
\text { Park Toptan } \\
\text { Elektrik } \\
\text { Konya Ilgin } \\
\text { Enerji }\end{array}$ & $\begin{array}{l}\text { Eti Soda } \\
\text { Ciner Resources } \\
\text { LP } \\
\text { Kazan Soda } \\
\text { Park Cam }\end{array}$ & $\begin{array}{l}\text { Ciner Havacılık } \\
\text { Havaş Turizm }\end{array}$ & & $\begin{array}{l}\text { Ciner Denizcilik } \\
\text { Park Denizcilik } \\
\text { Denmar Depoculuk } \\
\text { Park Sigorta } \\
\text { Kasımpaşa Spor Kulubü }\end{array}$ \\
\hline $\begin{array}{l}\text { Doğuş Grubu } \\
\text { (Ferit Şahenk) }\end{array}$ & $\begin{array}{l}\text { Doğuş Energy } \\
\text { Artvin Barajı } \\
\text { ve } \\
\text { Hidroelektrik } \\
\text { Santrali } \\
\text { Boyabat } \\
\text { Elektrik } \\
\text { Aslancık } \\
\text { Elektrik } \\
\text { Üretim A.Ş }\end{array}$ & & $\begin{array}{l}\text { Doğuş Yeme } \\
\text { İçe Turizm } \\
\text { D.Hotelier } \\
\text { ANTUR } \\
\text { Doğuş } \\
\text { Perakende }\end{array}$ & $\begin{array}{l}\text { Doğuş İnşaat } \\
\text { Teknik } \\
\text { Mühendislik } \\
\text { Doğuş } \\
\text { Gayrimenkul } \\
\text { Yatırım } \\
\text { Ortaklığ } \\
\text { Doğuş̧ } \\
\text { Gayrimenkul } \\
\text { Yatırım ve } \\
\text { İşletme }\end{array}$ & $\begin{array}{l}\text { Garanti BBVA } \\
\text { Garanti Mortage } \\
\text { Garanti Emeklilik ve } \\
\text { Hayat } \\
\text { Garanti Leasing } \\
\text { Garanti Yatırım } \\
\text { Garanti Factoring } \\
\text { Garanti Filo } \\
\text { Doğuş Oto } \\
\text { Related Marketing } \\
\text { Cloud(Dijital Pazarlama } \\
\text { Uygulaması) } \\
\text { Salıpazarı Liman } \\
\text { İşletmeciliği } \\
\text { Zingat (Emlak) } \\
\text { N11.com } \\
\text { Gyan }\end{array}$ \\
\hline
\end{tabular}

Türkiye'deki medya yapılanması yukarıda bahsettiğimiz mevcut durumdan da anlaşılacağı gibi, büyük holdinglerin egemen olduğu tekelleşmenin ve holdingleşmenin izlerinin yoğun olarak yaşandığı görülmektedir. Büyük holdingler mevcut güçlerini sürekli olarak daha ileriye doğru taşırken küçük 
işletmeler ise ciddi ekonomik krizlerle boğuşmakta ya da yok olmaktadır. Büyük sermaye sahipleri ellerinde bulunan güç ve otorite ile siyasi iktidarlarla daha yakın ilişkiye girebilmekte ve bunu kendi lehlerine kullanarak ayrıcalık elde etmektedir.

Tekelleşme olgusu basın üzerinde oldukça etkili bir sorun olarak görülmektedir. Zira günümüzde medya sektörü holdinglerin birbirleri ile yarıştığı bir alana dönüşmüştür. Holdinglerin çatısı altında olmayan veya büyük sermaye grupları tarafından destek bulamayan işletmeler sektöre dahil olmak istememektedir. Çünkü bu işletmeler medya holdingleri ile kıyaslandığında tiraj, dağıtım ve reklam konularında oldukça geride kaldıkları görülmektedir.

\section{Medyanın Tekelleşmesinin Olumsuz Sonuçları}

Medya kuruluşları her ne kadar bağımsız olma ve tekelleşmeye karşı direnç göstermiş olsa da bu işletmeler kapasite, tiraj, üretim maliyetlerinin fazlalığı, dağıtım sorunları gibi pek çok etkenle mücadele etmek zorunda kalmaktadır. Bunu başaramayan kuruluşlar ya kapanmak zorunda kalmakta ya da büyük şirketlerini safına katılmaya mecbur bırakılmaktadır. Tekelleşme medya için ciddi tehditleri beraberinde getirmektedir. Bu tehditler (Ilgaz, 2001, s. 220);

- Aynı sermaye kuruluşları tarafından farklı gazetelerde farklı yazı işlerinde benzer haberler oluşturulmakta çok seslilik engellenmektedir.

- Gazetecilik asıl fonksiyonu olan haber verme işlevini terk ederek yerine eğlence ve magazin ağırlıklı içerik varlığı artmakta, içerik kalitesi düşmektedir.

- Gazeteler ve gazeteciler medya patronlarının ve onların çıkar gruplarının aleyhine içerik oluşturması engellenirken bu durum gazetecilerin özgür çalışamaması problemini doğurmaktadır.

- Medya siyaset ilişki daha da karmaşık hale gelerek şaibeli ortamın doğmasına yol açmaktadır.

- Küçük medya kuruluşları varlıklarını sürdürmekte zorlanırken ya kapanmakta ya da büyük medya kuruluşlarına eklenmektedir.

- İstihdam sorunları daha da derinleşerek basın sektöründe çalışacak kalifiye eleman sayısı azalmaktadır.

\section{Sonuç}

Herman ve Chomsky'nin ifade ettiği Propaganda Modeli’nin ilk süzgeci olan kitle medyasının büyüklüğü ve kar anlayışı medyayı tekelleşen bir ortam haline getirmiştir. Medya patronları bankacılık, finans, enerji, hizmet, turizm, otomotiv, sanayi, ticaret, tekstil, madencilik gibi pek çok alanda faaliyet göstermektedir. $\mathrm{Bu}$ kişiler aynı zamanda medya yatırımlarını haber ajansları, kitap, dergi, reklam ajansları, yapım ve prodüksiyon gibi alanlara yönelterek sektörle ilişkili faaliyetleri çeşitlendirmiş ve her alanda kendi tanıtımını yapabileceği kendi görüş ve düşüncelerinin egemen olabileceği birer ortam yaratmıştır. Medyayı elinde bulunduran kişiler ülke gündemine yön vermelerine ek olarak sürekli kazanan kazandıkça ise medyanın farklı alanlarına yatırım yapan ve tekelleşen kişilere 
dönüşmektedir. Bu durum ise medyada tekelleşme uygulamalarının daha sert ve güçlü şekilde yaşanmasının önünü açmaktadır.

Tekelleşmenin artması medyadaki heterojen yapının ortadan kalkmasına zemin hazırlamaktadır. Belirli grupların hakimiyeti altında aynı ideoloji çerçevesinde yapılan haber içerikleri, isimleri birbirinden farklı araçlarda farklı başlıklarla karşılaşılmasına rağmen temelde sundukları görüşün aynı olduğu görülmektedir. Medyanın dördüncü güç olarak tanımlandığı dönemde gazeteler kamuyu aydınlatma ve denetleme işlevine sahip birer unsur olarak görev yapmıştır. Ancak gelinen bu noktada medya bu işlevinden uzaklaşmış, bunun yerine belirli görüşlerin kamuoyu ile paylaşıldığı bu tema dışındaki düşüncelerin ise görmezden gelindiği veya marjinalleştirildiği bir mecra yaratılmıştır. Farklı görüşlerin paylaşlamadığı ortamda medyanın kamuoyunu ne kadar bilinçlendirebileceği büyük bir soru olarak karşımıza çıkmaktadır. Sektöre yeni girecek işletmeler ise mevcut ortamda yarışamayacaklarını bilmelerinden dolayı bu mecralarda yer alma fikrine sıcak bakmamaktadır.

Tekelleşmenin medya üzerinde yarattığı etkiler yadsınamaz bir gerçek olarak görülmektedir. Yaratılan bu medya ortamında sadece büyük ve güçlülerin ayakta kalabileceği küçük ve güçsüzlerin sektöre girmeye cesaret edemediği girse de kısa sürede ekonomik darboğaz yaşayacağı bir ortamın doğmasına zemin hazırlamaktadır. Bu noktada devletin organlarının bazı desteklemeler ve yürürlüğe koyacağı kanunlar ile tekelleşmenin etkisi nispi olarak azaltılabilir. Örneğin sektöre yeni giren işletmelere vergi muafiyeti getirmek, işletmelerin ödemesi gereken primlerin devlet tarafından karşılanması, kamu reklamlarından daha fazla pay alması, faizsiz veya düşük krediler sağlanması gibi uygulamalarla sektör cazip hale getirilip yeni işletmelerin medyaya katılması için imkân yaratılabilir. Sonuç olarak değerlendirdiğimizde Herman ve Chomsky'nin ilk süzgecinin hala geçerli olduğunu ve Türk medyasının tekelleşen medya gruplarının egemenliği altında olduğu görülmektedir. Ancak alınacak önlemler ve sağlanacak bazı destekler ile medyada tekrar çok sesli farkı ideoloji ve içeriklere sahip yayın organlarının var olacağı bir ortamın yeniden doğuşu sağlanabilir.

\section{Kaynakça}

Adaklı, G. (2010), "Neoliberalizm ve Medya: Dünyada ve Türkiye de Medya Endüstrinin Dönüşümü”, Mülkiye Dergisi, 34(269), 67-84.

Avşar, Z. (2004). "Medyada Yoğunlaşma ve Şeffaflaşma: Yasal Düzenlemeler, Beklentiler, Sorun Alanları” İletişim Araştırmaları Dergisi, 2(2),121-144.

Bayram, Y. (2013). Küreselleşme Sürecinde Medya Sektörünün Değişen Doğası ve Türk Medya Sektörüne Yansımaları. Emek ve Toplum Dergisi. 2.(3), 235-261.

Ben B. (1987). The Media Monopoly, (2. Baskı). Boston: Beacon Press.

Bulunmaz, B. (2011). Holdingleşme Ekseninde Türk Medyasında Tekelleşme Sorunu. Öneri Dergisi. 9(36), 237-246.

Chomsky, N. (1993). Medya Gerçeği, (1. Baskı). İstanbul: Tüm Zamanlar Yayıncılık. 
Çetin, E. ve Tüzer, C. (2017). İnci Dergisi Üzerine Bir İnceleme. Milli Eğitim Dergisi, 46(246), 203-255.

Gaye T. (1972). “Objectivity as Strategic Ritual: An Examination of Newsmen's Notions of Objectivity", American Journal of Sociology 77(2), 662-664.

Güngör, N. (2013). İletişim Kuramlar Yaklaşımlar, (1. Baskı). İstanbul: Siyasal Kitabevi.

Güreli, N. (2004). Şu Bizim Medya, (1. Baskı). İstanbul: BAS-HAŞ Yayınları.

Herman, E. ve Chomsky N. (1999). Medya Halka Nasıl Evet Dedirtir, (2.Baskı). (B. Akyoldaş, Çev.). İstanbul: Minerva Yayınları.

Herman, E. ve Chomsky N. (2006). Rızanın İmalatı: Kitle Medyasının Ekonomi Politiği, (2.Baskı). (Ender Abadoğlu, Çev.) İstanbul: BGST Yayınları.

Ilgaz, C. (2001). Tekelleşme Olgusu ve Türk Basını. İstanbul Üniversitesi İletişim Fakültesi Dergisi. (11), 219-222.

James C. ve Jean S. (1985). Power Without Responsibility: The Press and Broadcasting in Britain, (2. Baskı). Londra: Methuen, Press.

Joseph T. (1984). Media Industries: The Production of News and Entertainment, London: Longman Press

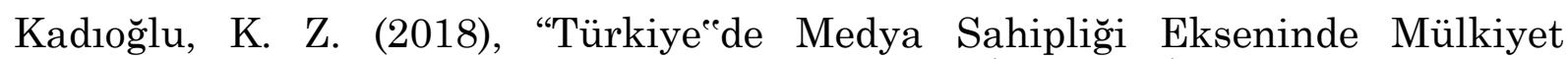
Yapılarındaki Değişim Kronolojik Analizi”, İnsan \& İnsan Dergisi, 5(16): 100-120.

Kılıçatan, P. (2011). Türk Medyasında Dönüşüm ve Değişen Sahiplik Yapısı Sabah Grubu Örneğinde Tarihsel Bir Inceleme, (1.Baskı). Konya: Literatürk Yayınevi.

Kuyucu, M. (2013). Türkiye'de Çapraz Medya Sahipliği: Medya Ekonomisine Olumsuz Etkileri ve Bu Etkilerin Önlenmesine Yönelik Öneriler. Selçuk İletişim Dergisi. 8.(1), 144-163.

Mark F. (1980). Manufacturing the News, Austin: University of Texas Press.

Özer, N. (2019). Propagandada Yöntemler, Araçlar ve Bir Propaganda Modeli Olarak; Herman ve Chomsky Propaganda Modeli. Kritik İletişim Çalışmaları Dergisi. 1.(1) 15-30.

Özgüven, A. (1991). İktisat Bilimine Giriş, (6. Baskı). İstanbul: BETA Yayınları.

Shoemaker, P. ve Reese, Stephen D. (2014). İdeolojinin Medya İçeriği Üzerindeki Etkisi, Medya, Kültür, Siyaset, (1.Baskı). Ankara: Pharmakon Yayınevi.

Tokgöz, O. (2008). Temel Gazetecilik, (13.Baskı). Ankara: İmge Kitabevi.

Yaylagül, L. (2019), "Eleştirel Ekonomi Politik Bakış Açısından Medyada Tekelleşme Sorunu”, İletişim ve Kuram Araştırma Dergisi, (48): 404-418.

Yöyen, B. (2007), Türkiye'de Basın Çalışanlarının İstihdam Sorunlarının İncelenmesi. Yayınlanmamış Yüksek Lisans Tezi, Dokuz Eylül Üniversitesi Sosyal Bilimler Enstitüsü, İzmir. 